\title{
The Review Study of Halal Products and Its Impact on Non-Muslims Purchase Intention
}

\author{
Muhammad Fikry Aransyah ${ }^{1}$, Finnah Furqoniah ${ }^{2}$, Amjad Hamad Abdullah ${ }^{3}$ \\ Universitas Mulawarman ${ }^{1,2}$, Erbil Polytechnic University, Kurdistan, Iraq ${ }^{3}$ \\ fikryaransyah@fisip.unmul.ac.id ${ }^{I}$ \\ finnahfurqoniah@fisip.unmul.ac.id ${ }^{2}$ \\ amjad.shernawyI974@mail.com ${ }^{3}$
}

\begin{abstract}
In a Muslim country, halal products were a norm in the society whereby Muslims in their daily life were not only consuming the halal products. The acceptance of non-Muslims towards halal products is growing as well because of the strict process and laws to follow. It reviews studies and theories on customer's purchase intention on halal products and the concepts of price, awareness, availability, safety, ingredients, and quality of the halal products, which affect their purpose to buy from the perspective of non-Muslim. Fifty research article from 2009 to 2019 was chosen for this research. Besides, the halal products are also being monitored, certified, and enforced by the government. Halal products with certification will automatically gain the confidant of the consumers without any doubts. There are many types of research being conducted about the halal industry, but there is limited research being conducted to explore the non-Muslim consumers' purchase intention on halal products.
\end{abstract}

Keywords: halal products, purchase intention, non-muslim, literature review

\section{A. INTRODUCTION}

As far as food is concerned, according to (Mathew, 20I4), there were plenty of opportunities to focus primarily on the interests of non-Muslims. As fast-food outlets, KFC, Burger King, Taco Bell, and McDonald launched most halal food options in their menu in non-Muslim countries(Ali, A., Xiaoling, G., Sherwani, M., \& Ali, 2017). (Hong, M., Sun, S., Beg, A. R., \& Zhou, 20I8) said China ranked ninth in the Muslim world, and China's demand for halal food products is massive. China's halal industry is worth USD 2.I billion, with a growth rate of I0.0 percent per year (Hong, M., Sun, S., Beg, A. R., \& Zhou, 20I8).

IFANCA (Islamic Food and Nutrition Council of America) described Halal originating from Arabic as' legal; permitted' in line with religious beliefs that depict sanctioned behaviors adhering to the Sharia Law (Islamic Teaching) (Battour, M. \& Ismail, 2015). Today, the halal industry has become a viable 
worldwide market for products and services. Halal-conscious travelers from or within an Islamic country are booming in this industry (Zulkifli, W., 20I I).

Nevertheless, (Ali, A., Xiaoling, G., Sherwani, M., \& Ali, 2017) noted in their study that in a non-Muslim nation like China, halal food is not readily available. Besides, the same study also reported that there was also a problem with the authenticity of halal food available. In contrast to other Muslim-oriented countries, (Hong, M., Sun, S., Beg, A. R., \& Zhou, 2018) further revealed the immature and less developed certification procedure and halal sector in a nonMuslim country such as China. As the branded halal beef consists of pork, for instance, a severe incident occurred (Hong, M., Sun, S., Beg, A. R., \& Zhou, 2018).

Therefore, the level of knowledge of the halal concept of non-Muslims remains doubtful (Krishnan, S., Mohd Aderis, M. H. H., Azman, M. N., \& Kamaluddin, 2017). Indonesia's current government focus solely on halal logo and certification rather than developing the necessary knowledge about the halal concept (Wibowo, M. W. \& Ahmad, 2016). Through stringent rules and regulations granting halal certificates, the government has attempted to promote Indonesia as a halal center (Wibowo, M. W. \& Ahmad, 20I6). (Alqudsi, 20I4) mentioned that consumers' attitudes and behavior towards the level of understanding of halal and Islamic Dietary Codes and Rules remain an issue among the locals (Krishnan, S., Mohd Aderis, M. H. H., Azman, M. N., \& Kamaluddin, 20I7).

There have been numerous studies on the use of halal food by Muslims (Mathew, 20I4). Nevertheless, for non-Muslim consumers, consuming halal or non-halal food items is another choice. A lack of consistency and transparency in the manufacture of halal meat products could be one of the results of a lack of knowledge transmitted (Alqudsi, 20I4). Efforts should be made to educate and disseminate "what" to non-Muslims in order to increase the perception of pure consciousness.

The study will contribute to the popularity among Muslim consumers as well as non-Muslim consumers of halal items in Indonesia. It will collect the variables affecting the intention of buying non-Muslims halal items in Indonesia. (Awan, H. M., Siddiquei, A. N., \& Haider, 2015) further stated that Muslims and non-Muslims consumers were more worried about the food they buy and eat in recent years. The information collected can be used by the competent authority to draw up a proper plan to improve the consumption and production of halal food in Indonesia and to take advantage of export opportunities in other countries, consisting of an increasing Muslim population. (Hong, M., Sun, S., Beg, A. R., \& Zhou, 2018) further stated that Muslims in China had enjoyed new 
imported consumer goods as a result of income increment. The contribution of the halal industry towards the economy will create more jobs and business opportunities around the world, especially in a market like China.

\section{B. THEORITICAL}

\section{Concept of Halal Product}

(Mathew, 20I4) claimed that the concept of halal in the Quran means fair food that can be taken without confusion, which also means valid and permitted. Besides, (Said, M., Hassan, F., Musa, R., \& Rahman, 20I4) claimed in his study that halal is a lawful and acceptable Arabic word. Also, in the Holy Quran, God stated that to consume halal things, Muslims, and all human beings. (Wilson, J.A.J., \& Liu, 2010) mentioned that the word halal means permission in law in the Arabic language. In particular, (Haque, A., Sarwar, A., Yasmin, F., Tarofder, A. K., \& Hossain, 2015) emphasized that acceptable Holy Quran-based activities mean halal.

The demand for halal from Muslim and non-Muslim consumers is growing and gaining worldwide popularity.(Yunus, N. S. N. M., Rashid, W. E. W., Ariffin, N. M., \& Rashid, 20I4) estimated halal market value of USD2.3I trillion and become a new global market demand. (Hussain, I., Rahman, S. U., Zaheer, A., \& Saleem, 20I6) further stressed that halal food trading would consist of overall 20.0 percent of world trade, taking into account population growth as well as an increase in income.

According to (Henderson, 2016), when describing halal and haram in the context of food and drink, it means food and drink that can and can not be consumed by Muslims as listed in the Quran and the words of the Prophet and also from the legal point of view.(Mathew, 20I4) also confirmed that the Quran's definition of halal is permissible or permitted. Halal food, which can be eaten without uncertainty, therefore means allowable food. Halal food and beverages can be defined as things that individuals can eat without any legitimate evidence to disallow and also free of any unlawful or impure content (Said, M., Hassan, F., Musa, R., \& Rahman, 20I4). According to (Kotler, P., \& Keller, 2005), the advantages are given by the features of the item to meet consumer wishes and needs. The advantages conveyed and provided are also brand attributes. It can, therefore, be inferred that the consumer can use a robust marketing weapon to differentiate the products of a business from its rivals by providing more attractive features (Wan, M., \& Toppinen, 2016).

(Eliasi, J. R., \& Dwyer, 2002) stated in their study that nutrition is considered halal or haram by looking at the entire food system. If the source is haram and potentially harmful to an individual's psyche, body, and soul, the food 
is considered haram. Mashbuh means food divided into halal and haram. Healthy food is often associated with halal food. (Wan, M., \& Toppinen, 2016) stated that halal foods, including seafood, frozen foods, canned foods, meats, seasoning, pasta and noodles, sauce, beverages, and packaged cooking sauces.(Said, M., Hassan, F., Musa, R., \& Rahman, 20I4) stated that the slaughtering procedure must follow the Islamic manner and be legally obtained in order for animal meat to be considered halal.(Hussain, I., Rahman, S. U., Zaheer, A., \& Saleem, 2016) made it clear that halal goods should be free from illegal or prohibited in the manufacture of sweets, toiletries, cakes, and so on, such as pork, alcohol, and animal oil. A further study conducted mentioned that halal means at the point when utilized about food in any structure at throughout exchange or business or as a significant aspect of an exchange description, is connected to legitimate items or foods or beverages(Ambali, A. R., \& Bakar, 20I4). (Lee, S. H., Siong, K. C., Lee, K. S., \& Kim, 2016) mentioned that the coverage of the halal concept is extensive, which includes the medical industry, banking, clothing, hotel management, cosmetics, and other types of businesses.

According to (Awan, H. M., Siddiquei, A. N., \& Haider, 2015), research on the variables that affect the purchasing of halal food products is being carried out. However, their study examined the differences between the attitudes of consumers towards halal food products and only halal cosmetics. (Said, M., Hassan, F., Musa, R., \& Rahman, 20I4) mentioned that many reasons affect the intention of the consumers to buy halal food items and their behavior. The reasons for this are the lack of information, the trust of consumers in the halal logo, the doubts about the value of eating healthy products, and the rate of special education. However, numbers are restricted when it comes to market recognition research among nonMuslim consumers.

\section{METHODOLOGY}

Every article of primary source material in the research area of purchase intention could not be sampled. This research includes a variety of characteristics of the above mentioned past research but is different in several significant respects. The period from 2009 to 2019 was chosen for this research. This analysis is restricted by the number of publications that can be examined in depth. Long-run and well-respected journals have been selected that are international and promote high-quality work through a double-blind peer-reviewing. Fifty journals have been selected to identify the 'best' halal product purchase intention research and are widely recognized as top journals in the field. The authors used a systematic literature review (SLR) for our review research on halal products and their impact on non-muslims consumers' purchase intention. Authors concentrate 
only on empirical articles. Exclude conceptual documents, real literature reviews, or papers where the halal products and its impact on non-muslims consumers' purchase intention was a peripheral component of the research.

\section{RESULTS AND DISCUSSION}

\section{Purchase Intention}

According to (Azam, 2016), the intention is the state of an individual's willingness to conduct the behavior and is regarded as a rapid antecedent of actions. Also, the intention to purchase can be defined as an individual's condition is to be prepared to buy such products. Besides, it is also mentioned that the attitude and behavioral purpose of an individual are influenced by the dietary patterns and the decision-making of the aid during the purchase process (Lee et al., 2016). Several previous studies have used the Planned Behavior Theory (PBT) to explain the purpose of a person to buy, use, and accept Halal food products (Rahim, N. A., \& Junos, 2012).

The purpose of taking or buying food, other than religion, is also associated with a positive or negative attitude, social weight, and the person's power. Based on the TPB, perceived behavioral regulation, behavioral disposition, and the subjective standard was seen as the components for predicting and clarifying actions and purpose.(Ozgen, O., \& Kurt, 2013) reported that research could be carried out to determine the relationship and impact of consumer attitude with the purchase of halal items.

(Wan, M., \& Toppinen, 2016) stated that there would be buying behaviors or buying intentions after the consumers considered and evaluated the product. This same study that the purchasing behavior of consumers and their subjective desires could be predicted and used as a critical point. It is, therefore, considered to be a useful tool used by most marketers to predict the buying intention of the consumers (Khemchotigoon, Y., \& Kaenmanee, 2015)(Yeow, 2019).

\section{Product Quality}

(Ryu, K., \& Han, 20I0) reliably demonstrated that performance parts, including the essence of food, atmospherics, and administration, fundamentally influence fulfillment in their findings on the diners ' procedure in making a decision, and such connections adequately explained the goal's growth.(Sumirah M. R., Nurul F. I., Zaw Z. H., \& Wai, 2015)reported that the execution of halal food certification increased customer confidence. In his report,(Hussain, I., Rahman, S. U., Zaheer, A., \& Saleem, 2016) claimed that there are only a few local approved bodies in Pakistan that, given many efforts to build up the halal industry, can meet the halal quality standards. It is also a concern for the nonMuslims towards health issue which arises around the world (Abdul Latiff, Z.A., 
Mohamed, Z.A., Rezai, G., \& Kamaruzzaman, 2013). Besides, (Mathew, 20I4)mentioned that products with high quality mean the products get a positive response from the consumers in terms of cleanliness and freshness.

Roininen, et. al. (200I) claimed that nowadays, because of the longer lifespan and also the quality of the food they can eat, the consumer is becoming more conscious of a particular food, and it is also a quality standard for consumers. Non-Muslims also claim that food with a halal logo is hygiene and safe to eat, according to (Mathew, 20I4). In today's globalization world, halal is now regarded as a quality of hygiene and healthy fashion, not just linked to religious needs. Besides,(Das, 20I4) also mentioned that companies should know how the consumers evaluate the product quality because consumers sometimes do not mind about the cost of purchasing that product or services, but rather the quality of it.

Perceived quality is one of the variables that influence the intention to buy, according to (Das, 20I4). Besides,(Das, 20I4) also mentioned that companies should know how consumers evaluate the quality of the product because sometimes consumers do not care about the cost of buying the product or services, but rather the quality of the product. Perceived product quality has had an impact on consumer satisfaction in the retail business, according to (Khemchotigoon, Y., \& Kaenmanee, 20I5). Also, the same study reported the findings of South Korea, Singapore, and Canada's mobile phone industry, which found that customer satisfaction had an impact on perceived product quality and performance. (Ismail, I., Abdullah, N. A. N., Ahmad, Z., \& Sidek, 20I8)stated that there is an essential link between halal intention to buy hygiene and clean process in Muslim consumers.

Indonesia has become the centerpiece of halal foods. Because it characterizes the cleanliness and freshness of the items, consumers will always react positively and recognize top quality items. (Mathew, 20I4)claimed in the same research on halal food acceptance that all consumers are generally concerned about food safety. It is essential to think about what is being put into the body as it turns out to be an individual item depending on the Islamic viewpoint (Mathew, 20I4; Yeow, 2019).

\section{Product Price}

(Kaura, 20I2), the real cost of the product and service is determined by the objective and subjective experience of the consumer. Price is detectable more rapidly than value as a heuristic sign (Yoon, S., Oh, S., Song, S., Kim, K. K., \& Kim, 20I4). In their study, (Lien, C. H., Wen, M. J., Huang, L. C., \& Wu, 20I5) mentioned that buyers would usually have a cost scope worthy of a proposed 
purchase. Price is considered an essential element in advertising products, and the price response is defined as the rate of reaction. Consumers were aware of changes in the cost of products and services (Low, W. S., Lee, J. D., \& Cheng, 2013). (Cho, Y. S., Rha, H. S., \& Burt, 20I5)stated that the significant factor influencing the purchase of retail brands affected by the concern for the price paid relative to the quality received, which is the value consciousness.

A study conducted by (Dominique-Ferreira, S., Vasconcelos, H., \& Proença, 2016) reported that pricing has also been debated over the past few decades because it is difficult to estimate and has also influenced business profit. Therefore, the challenge of setting the right price often means that not all consumers are willing to pay for a given item at a comparable value. (DominiqueFerreira, S., Vasconcelos, H., \& Proença, 2016) have noted that the company's overall revenues and market acceptance were taken into account in the pricing strategies. The chances of success in achieving the corporate profitability goal will be higher if managers have more information and well-equipped with the reactions of consumers over the price.

Furthermore, in a study on organic food in southern Gujarat, most consumers are willing to pay similar costs for the natural food being produced (Sharma, S., Shukla, R., Leua, A., Parmar, G., \& Chaudhari, 2016). According to(Low, W. S., Lee, J. D., \& Cheng, 2013), when buying a product or service, consumers may assess their satisfaction by contrasting the quality at a price to be charged and also the costs incurred when purchasing the products or services with other comparable purchases. In the same study, it also stated that consumers would not commit any further purchase or future purchases with the same retailer if being found out that the price being paid is high and the outcome of the product was unsatisfying.

The factor that influences the behavior intentions of the consumers is price, according to (Liang, L. J., Choi, H. C., \& Joppe, 2018). In their study, it is also stated that consumers will take different considerations based on the differences in pricing. Consumers do not generally remember the actual costs of items. Besides, some studies have also shown that purchasing is the probability that a customer will purchase a particular item or service (Hussain, I., Rahman, S. U., Zaheer, A., \& Saleem, 2016; Yeow, 2019).

In this report,(Cho, Y. S., Rha, H. S., \& Burt, 2015) findings reported that the significant factor affecting the purchasing of retail products influenced by the concern for the price paid compared to the quality obtained, which is the value perception, will be used. According to (Yang, 2017), the acceptance of halal food by non-Muslim consumers is significantly linked to the price of the halal item. (Lien, C. H., Wen, M. J., Huang, L. C., \& Wu, 2015)claimed that a price range 
would be suitable for the purchasing of expected buyers. In their findings, Hsu, Chang, and Yansritakul (2017) also stated that the price significantly impacts the final purchase decisions of consumers and the evaluation of alternative products.

\section{Product Availability}

In order to improve sales and revenue, according to (Moussaoui, I., Williams, B. D., Hofer, C., Aloysius, J. A., \& Waller, 2016), many retailers believe there is a need to improve the product's on-shelf availability (OSA). (Aastrup, J., \& Kotzab, 2009) stated that OSA and the critical execution pointer in the retail business are the primary components of customer service. If the consumer looks for the commodity on the shelf, the item's probability is available in a saleable state (Aastrup, J., \& Kotzab, 2009). Therefore, (Moussaoui, I., Williams, B. D., Hofer, C., Aloysius, J. A., \& Waller, 2016)stated that poor OSA would harm customer demand and also the loss of sales.

Generally speaking, consumers agree that if they have more resources such as energy, money, specialty shops, and skills, will mean that their perception of power is stable, and their social expectations have increased(Alam, S.S., \& Sayuti, 20II; Omar, K.M., Mat, N.K., Imhemed, G.A., \& Ali, 20I2). As a result, the more control a Muslim customer feels about eating halal food, the more chances they are planned to do as such. A study by (Siddiquei, A. N., Raza, M. A., Awan, H. M., \& Bukhari, 20I3)reported that low consumer brand loyalty is due to the lack of product availability, a key element in a country like Pakistan. However, some studies in the organic food segment set up showed no significant connection between the accessibility of natural food items and cost with purchase goals. Nevertheless, from the research conducted by (Sharma, S., Shukla, R., Leua, A., Parmar, G., \& Chaudhari, 2016) about organic food products in south Gujarat, it mentioned that because of the lack of availability of the products, two-thirds of the consumer had never tried it.

According to Elseidi (2018), it may be impossible to consume manageable items for consumers with low perceived availability of economic items. We ensure that this problem is associated with the lack of local food shops or business sectors of producers, which often fall short of the quality and accommodation requested by consumers. Perceived availability of halal personal care items has a critical impact on the intention of purchasing these items (Yeow, 2019).

(Awan, H. M., Siddiquei, A. N., \& Haider, 2015)reported that consumers have many options in Pakistan due to the availability of halal goods. Furthermore, authority and government are also responsible for the availability of food (Awan, H. M., Siddiquei, A. N., \& Haider, 20I5). As a customer, when needed, the easy way to find halal food products directly encourages non-Muslim consumers to buy halal food items. Consumers will generally buy it when items are effectively 
available on the market (Sharma, S., Shukla, R., Leua, A., Parmar, G., \& Chaudhari, 2016). This study about organic food products in south Gujarat, whereby the study mentioned that because of the lack of availability of the products, two-thirds of the consumer had never tried it (Sharma, S., Shukla, R., Leua, A., Parmar, G., \& Chaudhari, 2016). One of the measurements being used in their study stated that organic food is hard to prove positively affecting the consumer purchase on organic food. (Yang, 2017) also mentioned that the readily available information and beautiful storefront design did affection the nonMuslim buyer's acknowledgment.

\section{Product Ingredients}

From an Islamic viewpoint, brand additives suggest that consumers are conscious of the value, protection, and ingredients used in food content(Yunus, N. S. N. M., Rashid, W. E. W., Ariffin, N. M., \& Rashid, 20I4). Furthermore, the same study stated that the decision to buy is related to the information about the ingredients of the product. (Ismail, I., Abdullah, N. A. N., Ahmad, Z., \& Sidek, 2018)further stated that consumers would gather information and knowledge about the ingredients of the product through food labeling. (Ambali, A. R., \& Bakar, 2014)mentioned that halal food consumption shows that ingredient and material are not unsafe to the wellbeing because Allah only allowed what is useful for a human being. Based on the Islamic guidelines, processed food and drink need to use an ingredient and raw materials, which is (Ambali, A. R., \& Bakar, 20I4). The same study also stressed that Muslim people must be alert of the process of handling, item packaging, and ingredients of the food and drinks. (Yunus, N. S. N. M., Rashid, W. E. W., Ariffin, N. M., \& Rashid, 20I4)emphasized that personal and environmental reasons; for example, promotional content and product ingredients are highly related to the consumers' aim to buy.

Also, (Yunus, N. S. N. M., Rashid, W. E. W., Ariffin, N. M., \& Rashid, 20I4)found out in their research that the information gathered by food labeling lets consumers know what they are eating. Also, the buying behavior of people will be reacted based on sufficient knowledge of the ingredients of the product. (Hussain, I., Rahman, S. U., Zaheer, A., \& Saleem, 2016)claimed that during the production process, manufacturers must fulfill the halal criteria to obtain and sell the consumer's trust in the halal packages. (Yunus, N. S. N. M., Rashid, W. E. W., Ariffin, N. M., \& Rashid, 20I4)made it clear that processing aids, storage, retailing, transportation, handling, and processing equipment are strongly linked to quality and safety, which is also included in halal food. Therefore, the knowledge, Shariyah, and information are incredibly significant when choosing their nourishment option by Muslims. 
(Hussain, I., Rahman, S. U., Zaheer, A., \& Saleem, 2016)also stressed in their report that the ingredients are the primary concern of consumers and manufacturers in halal food products. Consumers should not eat illegal ingredients such as cow, animal fat, and haram alcohol. Therefore, the same study claimed that product development and production processes need to be continuously modified for marketers required in order to understand the concept of halal. Besides, the analysis of food content and ingredients can be done with the advancement of technology before the production and marketing of food products to consumers. Lastly, the same study further stated that products with a certified logo and halal ingredients would be the attention of consumers to buy besides well-promoted products (Hussain, I., Rahman, S. U., Zaheer, A., \& Saleem, 2016; Yeow, 2019).

(Yunus, N. S. N. M., Rashid, W. E. W., Ariffin, N. M., \& Rashid, 20I4)mentioned that people would react differently in their buying attitude based on the product ingredient's knowledge. The same study also stressed that during the process of purchasing, the possibility of accepted or rejected is relatively related to the knowledge of the product ingredients. It is, therefore, based on the importance of information, Shariyah, and knowledge when Muslims decide on the food option. The familiarity of the customer with the quality and ingredients, as well as food safety, should be multiplied from the Islamic point of view..

\section{Product Awareness}

(Ambali, A. R., \& Bakar, 20I4) mentioned that a variety of food products and customer choices had been created by modern technology. Nevertheless, it also comes with additional substances and materials to manage food production with perfections and demands. The consumers are, therefore, puzzled, and most of them are unaware of what they have consumed or are devouring due to the various combinations and types of foods and products available for sale. Therefore, faith and belief are also suggested as a source of consumer behavior knowledge. Various religious groups ' knowledge, religious identity, orientation, and beliefs will influence their purchasing decision.

Intentional behavior protection implies knowledge in which the situation is meant to perceive and identify an object purposefully (Jang, S. O., \& Woo, 2015). The sense of knowledge' is defined as the information or perception of a particular subject, according to (Azam, 2016). Also, curiosity about the level of information about halal items among non-Muslims is evident (Krishnan, S., Mohd Aderis, M. H. H., Azman, M. N., \& Kamaluddin, 2017). However, teaching the non-Muslim about the benefits of halal is a tough thing to do(Yeow, 2019; Yunos, R. M., Mahmood, C. F. C., \& Mansor, 20I4). 
According to(Anderson, W. E., Fornell, C., \& Rust, 1994), consumers place their trust in the data source and also rely on the vendor or outside eyewitnesses to receive data. The government plays a vital role in providing education to target audiences about the potential for food safety and resources(Ambali, A. R., \& Bakar, 20I4). (Abd Rahman, A., Asrarhaghighi, E., \& Ab Rahman, 20I5)said that information could refer to a person's known facts, experiences, and feelings.

Besides, through learning and experience, awareness and awareness can also be gained. (Said, M., Hassan, F., Musa, R., \& Rahman, 20I4)mentioned that they would decide to acquire data and review data depending on different examples when making a decision, based on the data in the customer's memories. (Abdul Aziz, Y., \& Chok, 2013)also noted that the intention of non-Muslim consumers to buy is positively related to halal food knowledge. Exposure, religiosity, knowledge, and awareness are essential to identify the purpose of the customer to purchase takaful family insurance(Lee, P. Y., Ling, W. Y., Ng, S. C., Tan, K. R., $\&$ Wong, 2018).

Consumers need to rely on the dealer and give their trust to the data source, according to (Ambali, A. R., \& Bakar, 20I4). Findings suggested through education will be one of the techniques that will make people aware of what they are taking in terms of safety and clean condition, which is the fundamental point of halal. During their intake, it is also through education that people get exposure and make the right choices (Ambali, A. R., \& Bakar, 20I4; Yeow, 20I9). In their report, Rajagopal, Ramanan, and Satapathy (20II) proposed that better-used advertising and branding be made available and marketed via marketing communication. The same study further mentioned that consumers were not presented enough to halal accreditation and halal brands. (Husin, M. M., Ismail, N., \& Rahman, 2016)stated that mass media and word of mouth would affect the purchase intention of Takaful.

In this study, (Abd Rahman, A., Asrarhaghighi, E., \& Ab Rahman, 20I5)'s research stated that knowledge might refer to a person's known facts, experiences, and feelings. Also, awareness and awareness can also be gained through learning, and the study will use experience. Past reviews examining the correlation between a government job and buying intention found a unique positive relationship. In their study, (Awan, H. M., Siddiquei, A. N., \& Haider, 20I5)also mentioned that the marketing of halal food products was positively related to Pakistan's buying intention.

\section{Product Food Safety}

The types of food products on the market have expanded in the current world of globalization. Nevertheless, there have been continuously issues such as food with manufactured accreditation, lack of personality, and fake evidence, and 
the customer knows about it (Lee, S. H., Siong, K. C., Lee, K. S., \& Kim, 2016). The consumers will, therefore, always be worried about the food they eat and buy (An, HL., Sohn, JM., Choi, JM., \& Kim, 20I5). Under halal's condition, the food being processed will be certified by a credible agency, giving them confidence, and becoming a consumer's primary choice of purchase(Abdul Aziz, Y., \& Chok, 20I3). An et al. (2015) also mentioned that a product is certified with halal is an essential component of the purchasing choice, and Muslim consumers demand it regardless of their country of life. It helps them to understand better of Muslims' food practices and boundaries.(Hussain, I., Rahman, S. U., Zaheer, A., \& Saleem, 2016) mentioned that non-Muslim also familiar with the halal concept, and it was not only limited to Muslims. Besides, the same study also stated that both Muslim and non-Muslim consumers demanded safer food than before.

Any food supplied in Indonesia can not include components that are harmful to well-being during the process of preparation, sales, and use. It will be regulated by Law No. 33 of 2014 on halal consumer insurance ("Halal Law"), which governs the ingredients, manufacturing, and certification of halal products, as well as international cooperation with foreign halal certification agencies, passed by the House of Representatives. Previously, halal certification was not set under any law and was implemented by the Indonesian Islamic Clergy Council (Majelis Ulama Indonesia - "MUI"). Following MORA Decree No. 5 I9 of 30 November 200I, MUI was explicitly appointed by the Minister of Religious Affairs ("MORA") for halal certification of food.

Halal certification of products was implemented by MUI's Food and Drugs Supervisory Agency (Lembaga Pengawasan Pangan Obat dan Makanan Majelis Ulama Indonesia - "LPPOM MUI"). According to (Yang, 20I7), who carried out a case study on variables that affect the conduct of non-Muslim buying on halal food, the security of halal food has a significant effect on non-Muslim consumers. (Ambali, A. R., \& Bakar, 20I4)stressed that keeping the food, the halal definition, and the things around us are clean, particularly in food issues, to prevent disease. Accordingly, (Ambali, A. R., \& Bakar, 20I4)claimed that a portion of healthy food, drink, or product that does not cause harm to consumers when it is arranged and consumed or to understand its proposed use, including Muslims and non-Muslims.

In Indonesia, consumer attention is being paid to food safety, and it is gaining consumer acceptance. This organic and halal food outlet can be seen in Indonesia by the number. (Abdul Aziz, Y., \& Chok, 2013)stated that the halal logo provided food products with assurance and recognition. (Haque, A., Sarwar, A., Yasmin, F., Tarofder, A. K., \& Hossain, 2015)reported that there was 
significant concern regarding food quality and health from producers, buyers, authority, and food producers.

Quality and food security in Malaysia is an unequivocally significant issue, according to (Haque, A., Sarwar, A., Yasmin, F., Tarofder, A. K., \& Hossain, 20I5). Pesticides being misused is a problem and affects the level of food security(Yeow, 2019). For non-Muslims, our multi-cultural practices make the consumption of halal food standard in Indonesia. (Yang, 2017), in his study, did mention that the safety of halal food significantly affects the non-Muslim consumer's acknowledgment of halal food items. (Hussain, I., Rahman, S. U., Zaheer, A., \& Saleem, 2016)mentioned that the consumer reacts to the food safety and quality of the halal products beyond religion. It is because the halal product is considered stricter in terms of safety and quality requirements than the non-halal items. According to (Mathew, 20I4), non-Muslims also think that food with a halal logo is hygiene and clean to consume.

\section{E. CONCLUSION}

Based on the literature review being conducted about the general halal industry, halal regulations and various factors influencing the consumer's intention to buy, the researcher had identified several areas in the literature, which can be further explored. There are many types of research being conducted about the halal industry, but there is limited research being conducted to explore the nonMuslim consumers' intention to buy halal products. Factors like the impact of product availability, product ingredients, and product price, which might significantly influence the intention to buy halal food by non-Muslim, can be further explored. Therefore, this research plan to further study and gather more comprehensive data on the interrelationships between product price, product quality, product safety, product awareness, product availability, and product ingredients, which will affect the non-Muslim consumers' intention to buy halal food items.

\section{REFERENCES}

Aastrup, J., \& Kotzab, H. (2009). Analyzing out-of-stock in independent grocery stores: An empirical study. International Journal of Retail \& Distribution Management, 37(9), 765-789.

Abd Rahman, A., Asrarhaghighi, E., \& Ab Rahman, S. (2015). Consumers and Halal cosmetic products: knowledge, religiosity, attitude, and intention. Journal of Islamic Marketing, 6(I), I48-I63.

Abdul Aziz, Y., \& Chok, N. V. (2013). The role of Halal awareness, Halal 
certification and marketing components in determining Halal purchase intention among non-Muslim in Malaysia: A structural equation modeling approach. Journal of International Food and Agribusiness Marketing, 25(I), I-23.

Abdul Latiff, Z.A., Mohamed, Z.A., Rezai, G., \& Kamaruzzaman, N. . (2013). The impact of food labeling on purchasing behavior among non-muslim consumers in Klang Valley. Australian Joutnal of Basic and Applied Sciences, 7(I), I24-I28.

Alam, S.S., \& Sayuti, N. . (20II). Applying the Theory of Planned Behaviour (TPB) in halal food purchasing. International Journal of Commerce and Management, 2I(I), 8-20.

Ali, A., Xiaoling, G., Sherwani, M., \& Ali, A. (20I7). Factors affecting Halal meat purchase intention: Evidence from international Muslim students in China. British Food Journal, II9(3), 527-54I.

Alqudsi, S. G. (20I4). Awareness and Demand for I00\% Halal Supply Chain Meat Products. Procedia - Social and Behavioral Sciences, I30, I67-I78.

Ambali, A. R., \& Bakar, A. N. (20I4). People's awareness of halal foods and products: potential issues for policy-makers. Procedia-Social and Behavioral Sciences, I2I, 3-25.

An, HL., Sohn, JM., Choi, JM., \& Kim, H. (20I5). Brand positioning strategy of franchise family restaurant. The Korean Journal of Culinaty Research, 2I(4), 339-348.

Anderson, W. E., Fornell, C., \& Rust, T. R. (I994). Customer satisfaction, productivity, and profitability: Differences between goods and services. Marketing Science, I6(2), I29-I45.

Awan, H. M., Siddiquei, A. N., \& Haider, Z. (20I5). Factors affecting Halal purchase intention-evidence from Pakistan's Halal food sector. Management Research Review, 38(6), 640-660.

Azam, A. (2016). An empirical study on non-Muslim's packaged halal food manufacturers: Saudi Arabian consumers' purchase intention. Journal of Islamic Marketing, 7(4), 44I-460.

Battour, M. \& Ismail, M. N. (2015). Halal tourism: Concepts, Practices, Challenges and Future. Tourism Maagement Perspectives, I9, I50-I54.

Cho, Y. S., Rha, H. S., \& Burt, S. (2015). The impact of customer awareness of manufacturer name disclosure on retail brand attitudes and loyalty in Korea. Journal of Retailing and Consumer Services, 22, I28-I37.

Das, G. (20I4). Linkages of retailer awareness, retailer association, retailer perceived quality, and retailer loyalty with purchase intention: A study of Indian food retail brands. Journal of Retailing and Consumer Services, 2I(3), 
Dominique-Ferreira, S., Vasconcelos, H., \& Proença, J. F. (2016). Determinants of customer price sensitivity: an empirical analysis. Journal of Services Marketing, 30(3), 327-340.

Eliasi, J. R., \& Dwyer, J. T. (2002). Kosher and Halal: religious observances are affecting dietary intakes. Journal of the Academy of Nutrition and Dietetics, IO2(7), $91 I$.

Haque, A., Sarwar, A., Yasmin, F., Tarofder, A. K., \& Hossain, M. A. (2015). Non-Muslim consumers' perception of purchasing halal food products in Malaysia. Journal of Islamic Marketing, 6(I), I33-I47.

Henderson, J. C. (2016). Halal food, certification, and halal tourism: Insights from Malaysia and Singapore. Tourism Management Perspectives, I9, I60I64.

Hong, M., Sun, S., Beg, A. R., \& Zhou, Z. (2018). Determinants of halal purchasing behavior: evidence from China. Journal of Islamic Marketing. IO(2), 4IO-425.

Husin, M. M., Ismail, N., \& Rahman, A. A. (2016). The roles of mass media, word of mouth, and subjective norm in family Takaful purchase intention. Journal of Islamic Marketing, 7(I), 59-73.

Hussain, I., Rahman, S. U., Zaheer, A., \& Saleem, S. (2016). Integrating factors influencing consumers' halal products purchase: application of the theory of reasoned action. Journal of International Food \& Agribusiness Marketing, 28(I), 35-58.

Ismail, I., Abdullah, N. A. N., Ahmad, Z., \& Sidek, N. L. (2018). Halal principles and halal purchase intention among Muslim consumers. In Proceedings of the 3rd International Halal Conference (INHAC 20I6) (Pp. I3I-I38). Springer, Singapore.

Jang, S. O., \& Woo, I. S. (20I5). A study on consumer awareness, preference, and consumption behavior regarding local food - Focusing on the Gyeongju area. The Korean Journal of Culinary Research, 2I(2):I54-I70.

Kaura, V. (20I2). A link for a perceived price, price fairness, and customer satisfaction. Pacific Business Review International Journal, 5(6), 84-88.

Khemchotigoon, Y., \& Kaenmanee, S. (2015). The relationship between consumer animosity, marketing mix, perceived product quality, consumer satisfaction, and intention to purchase of consumer behavior. International Business Management, 9(I), 70-78.

Kotler, P., \& Keller, K. L. (2005). Marketing Management, I2th ed. Pearson Education.

Krishnan, S., Mohd Aderis, M. H. H., Azman, M. N., \& Kamaluddin, M. N. A. 
(2017). Halal food: Study on Non-Muslim acceptance. American Journal of Economics, $7(I), 4 I-45$.

Lee, P. Y., Ling, W. Y., Ng, S. C., Tan, K. R., \& Wong, X. Y. (2018). Factors influence the intention of non-Muslims to choose Takaful based on their perception. Unpublished Doctoral Dissertation, Universiti Tunku Abdul Rahman.

Lee, S. H., Siong, K. C., Lee, K. S., \& Kim, H. S. (2016). Non-Muslim Consumers' Purchase Intention on Halal Food Products in Malaysia. Culinaty Science \& Hospitality Research, 22(I), IO8-II6.

Liang, L. J., Choi, H. C., \& Joppe, M. (2018). Understanding the repurchase intention of Airbnb consumers: Perceived authenticity, electronic word-ofmouth, and price sensitivity. Journal of Travel \& Tourism Marketing, 35(I), 73-89.

Lien, C. H., Wen, M. J., Huang, L. C., \& Wu, K. L. (20I 5). Online hotel booking: The effects of brand image, price, trust, and value on purchase intentions. Asia Pacific Management Review, 20(4), 210-2I8.

Low, W. S., Lee, J. D., \& Cheng, S. M. (2013). The link between customer satisfaction and price sensitivity: An investigation of the retailing industry in Taiwan. Journal of Retailing and Consumer Services, 2O(I), I-IO.

Mathew, V. N. (20I4). Acceptance of halal food among non-Muslim consumers. Procedia-Social and Behavioral Sciences, I21, 262-27I.

Moussaoui, I., Williams, B. D., Hofer, C., Aloysius, J. A., \& Waller, M. A. (2016). Drivers of retail on-shelf availability: Systematic review, critical assessment, and reflections on the road ahead. International Journal of Physical Distribution \& Logistics Management, 46(5), 516-535.

Omar, K.M., Mat, N.K., Imhemed, G.A., \& Ali, F. M. . (20I2). The direct effects of halal product actual purchase antecedents among the international Muslim consumers. American Journal of Economics, Special Issue, Pp. 87-92.

Ozgen, O., \& Kurt, S. D. K. (20I3). The purchasing behavior of Islamic brands: An experimental research. In 42nd Annual Conference of EMAC European Marketing Academy, Istanbul, Turkey.

Rahim, N. A., \& Junos, S. (20I2). The halal product acceptance model for religious society. Business and Management Quarterly Review, 3(I), I7-25.

Ryu, K., \& Han, H. (20I0). Influence of the quality of food, service, and physical environment on customer satisfaction and behavioral intention in quickcasual restaurants: the moderating role of perceived price. Journal of Hospitality and Tourism Research, 34(3),3IO.

Said, M., Hassan, F., Musa, R., \& Rahman, N. A. (20I4). Assessing consumers' perception, knowledge, and religiosity on Malaysia's halal food products. 
Procedia-Social and Behavioral Sciences, I30, I20-I28.

Sharma, S., Shukla, R., Leua, A., Parmar, G., \& Chaudhari, B. (20I6). Consumers' awareness and opinion regarding organic food products in south Gujarat. International Journal of Farm Sciences, 6(3), 206-215.

Siddiquei, A. N., Raza, M. A., Awan, H. M., \& Bukhari, K. S. (2013).

Determinants of manufacturer's selection of distributors: A case from pharmaceutical and electronic appliance industry. International Journal of Contemporary Business Studies, 4(I).

Sumirah M. R., Nurul F. I., Zaw Z. H., \& Wai, Y. N. N. (2015). Vision-based verification of authentic JAKIM Halal logo. ARPN Journal of Engineering and Applied Sciences. IO(2I). IOI22-IOI30.

Wan, M., \& Toppinen, A. (2016). Effects of perceived product quality and Lifestyles of Health and Sustainability (LOHAS) on consumer price preferences for children's furniture in China. Journal of Forest Economics, 22, 52-67. Inc., NJ.

Wibowo, M. W. \& Ahmad, F. S. (2016). Non-Muslim Consumers' Halal Food Product Acceptance Model. Procedia Economics and Finance. 37. 276-283.

Wilson, J.A.J., \& Liu, J. (20I0). Shaping the halal into a brand? Journal of Islamic Marketing, 2(I), IO7-I23.

Yang, H. (2017). Research on influencing factors of Halal food buying behavior by Non- Muslim consumers: A case study of Ningxia in China. Boletín Técnico, ISSN: 0376-723X, 55(I6).

Yeow, C. C. (2019). Consumers' Intention to Purchase Halal Products in Malaysia: A Case of Non-Muslims. Unpublished Master Thesis, Universiti Tunku Abdul Rahman.

Yoon, S., Oh, S., Song, S., Kim, K. K., \& Kim, Y. (20I4). Higher quality or a lower price? How value-increasing promotions affect retailer reputation via perceived value. Journal of Business Research, 67(10), 2088-2096.

Yunos, R. M., Mahmood, C. F. C., \& Mansor, N. H. A. (20I4). Understanding mechanisms to promote halal industry-the stakeholders' views. ProcediaSocial and Behavioral Sciences, I30, I60-I66.

Yunus, N. S. N. M., Rashid, W. E. W., Ariffin, N. M., \& Rashid, N. M. (20I4). Muslim's purchase intention towards non-Muslim's Halal packaged food manufacturer. Procedia-Social and Behavioral Sciences, I30, I45-I54.

Zulkifli, W., \& Y. (20I I). Developing the Framework for Halal Friendly Tourism in Malaysia. International Business Management, 5(6), 295-302. 